PUNJABI IMMIGRANT WOMEN IN THE GTA TRUCK INDUSTRY: A CASE STUDY

\author{
by \\ Bashinder Gill, B.A Hons. York University, 2010 \\ A Major Research Paper \\ presented to Ryerson University \\ in partial fulfillment of the requirements for the degree of \\ Master of Arts \\ in the Program of \\ Immigration and Settlement Studies
}

Toronto, Ontario, Canada, 2013

(C) Bashinder Gill 2013 


\section{AUTHOR'S DECLARATION FOR ELECTRONIC SUBMISSION OF A MAJOR RESEARCH PAPER (MRP)}

I hereby declare that I am the sole author of this Major Research Paper. This is a true copy of the MRP, including any required final revisions, as accepted by my examiners.

I authorize Ryerson University to lend this MRP to other institutions or individuals for the purpose of scholarly research

I further authorize Ryerson University to reproduce this MRP by photocopying or by other means, in total or in part, at the request of other institutions or individuals for the purpose of scholarly research.

I understand that my MRP may be made electronically available to the public. 


\title{
PUNJABI IMMIGRANT WOMEN IN THE GTA TRUCK INDUSTRY: A CASE STUDY
}

\author{
Bashinder Gill \\ Master of Arts 2013 \\ Immigration and Settlement Studies \\ Ryerson University
}

\begin{abstract}
The main purpose of this qualitative case study was to explore the growing phenomenon of Punjabi immigrant women from the GTA entering the male dominated trucking industry. In particular, this study aimed to explore the factors that enabled immigrant women to enter a nontraditional occupation and to examine the role of social capital in impacting their labour market outcomes. By interviewing 8 Punjabi immigrant women who have experienced driving a truck, the results of the study showed that living in an extended family household and the support of spouses played a major role in facilitating entry into the truck industry. Furthermore, the accumulation of social capital within Punjabi ethnic enclave communities also enabled women to enter trucking. Drawing on existing literature and government publications concerning the trucking industry, this study also helps to illustrate how immigrant populations become significant actors within particular industries, in this case, the GTA's trucking industry.

Keywords: truck driver, immigrant, Punjabi women, social capital
\end{abstract}




\section{Acknowledgments}

I would like to thank my supervisor for this project, Aparna Sundar, for her assistance, advice, and encouragement. Aparna Sundar's support made me feel confident in exploring a topic that has been understudied and her support also influenced me with continuing this project. I would also like to thank my second reader, Amina Jamal, for her support and assistance in this project. I am grateful to all of the female truck drivers who participated in this study and took time out of their busy schedules for an interview. Lastly, I would like to thank my friends and family for their support. 


\section{Table of Contents}

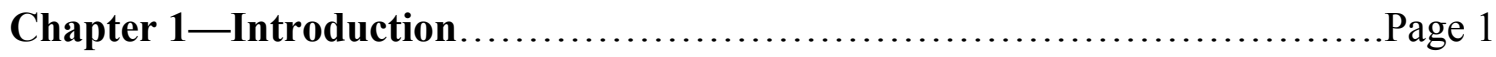

\section{Chapter 2- Social Capital in Immigrant Communities and Ethnic Enclaves}

2.1-What is Social Capital?.....

Page 5

2.2-The Importance of Social Capital

within the Trucking Industry....

2.3 - The Benefits of Living in an Ethnic Enclave Community. Page 11

2.4-Social Capital in the Punjabi Community......................................... 15

\section{Chapter 3-The Trucking Industry: A Background}

3.1-Economics of the Canadian Trucking Industry \&

the Effects of Deregulation

Page 21

3.2 - Women \& Immigrants in the Trucking Industry.

Page 25

3.3- Trucking in the Greater Toronto Area (GTA).

Page 27

3.4-Issues within the Canadian Trucking Industry

Page 28

\section{Chapter 4-Methodology}

4.1—Sample Size and Recruitment Methods....

Page 31

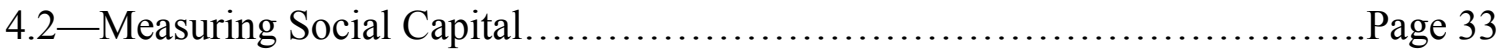

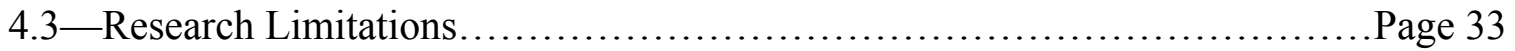

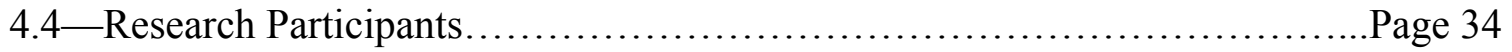

\section{Chapter 5-Findings and Overview of Recurring Themes}

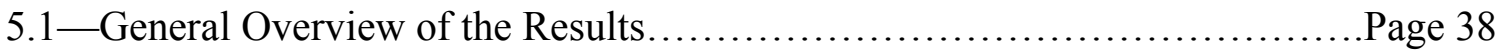

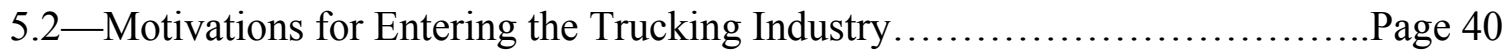

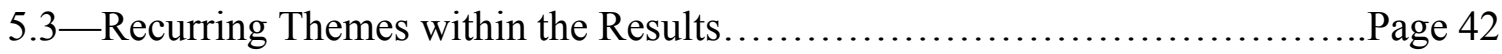




\section{Chapter 6-Discussion and Analysis}

6.1-Incidence of Social Capital and the

Density of Social Networks.

6.2 - The Significance of Familial Networks for

Punjabi Immigrant Women Drivers.

6.3 - Driving a Truck for more 'Capital' \& Access to

Resources in Ethnic Enclaves............................................Page 51

6.4-Does Race, Class, or Gender have an impact on the Punjabi Women Drivers?

Chapter 7-Conclusion .Page 57

References. Page 60 


\section{CHAPTER 1}

\section{Introduction}

Punjabi immigrant women entering the trucking industry in the Greater Toronto Area (GTA) is a growing phenomenon that is not as yet recognized in academic literature. Moreover, despite the enormous size and significance of the trucking industry to the economy, there is relatively little scholarly work on the industry from a Canadian perspective. As described by Toronto Star reporter Raveena Aulakh (2009), Punjabi women driving trucks are a "silent minority" in the GTA's trucking industry, which is increasingly dominated by Indo-Canadian men. By using social capital as a theoretical framework, this paper will demonstrate that the accumulation of social capital within immigrant populations can allow women to have access to unexpected or nontraditional jobs. In particular, this study will examine the role of social capital in facilitating labour market integration for Punjabi immigrant women employed in the male dominated trucking industry. Social capital can be defined as resources embedded in relationships among actors and contains two key dimensions: social networks and resources (Hauberer, 2011). Although the theory of social capital can be broad, it is nonetheless useful in describing whether or not the accumulation of informal networks, resources, etc., plays any role in enabling Punjabi immigrant women to enter the trucking business.

While many discussions of immigrants in Canada have explored the role of social capital in successful integration (Stone, Destrempes, Foote and Sharon Jeannotte, 2008), they have not addressed how social capital can allow particular immigrant communities to have access to unexpected channels, such as Punjabi immigrants in the GTA's trucking industry. Hence, this study will attempt to fill this research gap by focusing on a specific 
community, Punjabi immigrant women in the GTA, and the role of social capital in facilitating their entry into the trucking industry. In the West, media images and literature concerning South Asian immigrant women tend to have a strong undercurrent of common themes relating to victimhood, dowries, forced marriages, honour killings, and the lowly position of women in a highly patriarchal society or culture (Lau, 2007). However, this case study on Punjabi immigrant women truck drivers presents findings that challenge the common stereotypes of South Asian immigrant women. Moreover, this research can be beneficial for the general public since it can help deconstruct societal norms and expectations concerning gender roles. By exploring and analyzing the experiences of female truck drivers, dominant societal norms can be challenged since the research presents findings that give Canadians a new perspective on what they might consider to be a "man's job."

Immigrant populations from the Indian subcontinent are generally categorized under much broader labels such as South Asian, Indian, Indo-Canadian, etc. This disappearance of the regional and linguistic differences or distinctiveness of immigrants from the Indian subcontinent can distance one from the realities of immigrant communities in Canada, as well as create generalizations (Lau, 2007). Hence, it is significant to focus on one particular immigrant community in order to avoid the "oversimplification of the diverse images and identities of South Asia" (Lau, 2007, p.32). Although this study will attempt to focus on Punjabi immigrants in Canada, this research paper will draw upon various literatures that focus on South Asians or Indians as well, since there is limited literature available on Punjabi immigrants. 
The main purpose of this research paper is to explore the factors that enable Punjabi immigrant women to enter the male dominated trucking industry, as well as examine whether or not social capital plays a major role in determining labour market outcomes for Punjabi immigrant women. In certain regions of the GTA, such as the Peel Region, there is a high concentration of Punjabi immigrants and truck activity in Peel represents about 25 percent of all truck activity in Ontario (Khaderoo and Saiyed, 2012). Hence, it is important to question whether or not living in an ethnic enclave community has enabled Punjabi immigrant women to gain more social capital. The term ethnic enclave is used for areas in which a specific group dominates the population (Hiebert, 2009). In order to explore and collect data concerning immigrant women truck drivers, in-depth semi-structured interviews were conducted with 8 Punjabi immigrant women who are currently driving a truck or have been in the past. The scope and size of this research is limited to Punjabi immigrant women who reside in the GTA and have immigrated from Punjab, India.

It is important to note that this research paper is a mix of explanatory and exploratory research. Explanatory research aims to account for or explain some aspect of reality, whereas exploratory research aims to discover factors relating to a subject about which very little is known (Archer and Berdahl, 2011). In this research paper, I aim to explain why Punjabi immigrant women are choosing a nontraditional livelihood. Exploratory research is also applicable for this study since very little is known about Punjabi immigrant women driving trucks, which is why the inclusion of primary participants in the research was necessary. This case study on Punjabi immigrant women truck drivers has four main objectives: (1) to explore the phenomenon of Punjabi 
immigrant women entering the trucking industry; (2) to examine the factors that enable Punjabi immigrant women to enter the trucking industry; (3) to explore whether or not the accumulation of social capital has an impact on labour market outcomes for Punjabi immigrant women in the GTA; and (4) to examine whether or not living in an ethnic enclave community has enabled Punjabi immigrant women to gain more social capital. Consequently, the following research questions will be considered for this paper: Firstly, what are the factors that enable Punjabi immigrant women to enter the male dominated trucking industry? Secondly, what is the role of social capital, if any, in impacting labour market outcomes for Punjabi immigrant women in the GTA? Lastly, to what extent does living in ethnic enclave communities enable Punjabi immigrant women to gain more social capital? These research questions are essential since they will help frame the analysis of the paper.

Before addressing the research questions, the following chapter will focus on social capital in the Punjabi immigrant community and in the trucking industry, as well as the benefits of living in an ethnic enclave community. Furthermore, social capital will be defined and analyzed in the following section. Subsequently, a background of the Canadian trucking industry will be presented. In particular, the background chapter will provide an overview of the trucking industry and it will help one understand why the GTA's trucking industry is beginning to rely on the immigrant population for transporting goods across Canada and the United States. Following the background chapter, the methodology chapter will describe the methods used in this small-scale qualitative study, followed by the findings of the research. Lastly, a discussion and analysis of the findings will be presented, followed by a conclusion. 


\section{CHAPTER 2}

\section{Social Capital in Immigrant Communities and Ethnic Enclaves}

This chapter will draw upon previous literature and studies to define and analyze the concept of social capital, to examine the role of social capital within the Punjabi community and trucking industries, and examine the benefits of living in an ethnic enclave community.

\section{1-What is Social Capital?}

Defining social capital is not an easy task since there is not a shared consensus on the definition or to when and where the phrase "social capital" was first used. Also, the term 'capital' within the theory is considered to be controversial and misleading by some academics. As Pawar (2006) argues, it is necessary to look at the use of the precise language of the concept to see whether or not the phrase "social capital" matches the meaning conveyed by the word. In Pawar's (2006) content analysis study of eleven definitions of social capital (including those of Bourdieu, Coleman, and Putnam), it was revealed that the words that most frequently appeared in definitions of social capital were trust, networks, collective action, norms, relationships, and attitudes. Pawar (2006) further argues that the ideological roots of 'capital' suggest that it is individualistic and its multiplication tends to accumulate and concentrate often through exploitative means, as well as follow paths of gender and class discrimination. However, the phenomenon captured by the phrase social capital tends towards the social, rather than the individualistic. The term social capital spreads to families, communities, and groups, which is seen to be a contradiction (Pawar, 2006). Although the debate concerning the 
usage of the term 'capital' is important to consider, the theory can nonetheless be useful in describing social networks, which is an important form of social capital.

The theory or the concept of social capital is considered to be broad and elusive. However, broadly speaking, "social capital relates to the values that individuals and groups possess and the resources that they have access to which can promote, or result from, diverse social relationships and ties" (Mooney, 2006, p.385). Therefore, social capital is primarily concerned with social networks, forms of socialization, norms of reciprocity, social bonds, trust and resources and the multiple and changing relationships between them (Mooney, 2006). For immigrants, social capital can accumulate from both formal and informal networks. An informal network generally consists of friends and family that a newcomer can approach for help, whereas formal networks involve organizations, which offer numerous services to meet various settlement needs (Chaze and George, 2009). According to Galabuzi and Teelucksingh (2010), social networks or relationships perform a social function in individual and group interactions within broader structural contexts, such as political institutions, the health care system, labour markets and the education system (p.8). Social capital theory argues that people do better when they are connected to others because of goods (social capital) inherent in social relationships (Small, 2009). Hence, this theory is useful in describing how social networks and relationships Punjabi immigrant women may possess, enable them to overcome barriers and enter a male dominated industry.

One form of social capital that is noteworthy to mention for this particular study concerning Punjabi immigrant women is ethnic attachment. Ethnic attachment can be defined as the extent to which members of an ethnic or immigrant group maintain their 
native cultural tradition and social interactions with co-ethnic members (Min, 1993). Peter Li's (2004) reviews literature on immigrants and ethnic minorities to see how ethnic attachment, as a form of social capital, has affected the economic well being of immigrants and minorities. For Li social capital can be summarized in three elements that can potentially help with understanding how ethnic minorities and immigrant groups utilize social capital and how it may affect their economic well being: "First, social capital represents a form of resource that an individual may mobilize as a result of being attached to a social group" (Li, 2004, p.175). Secondly, the resourcefulness of social capital depends on the intensity and extensity of social ties or attachments present in the group and thirdly, the production or accumulation of social capital requires an individual to invest in and maintain social relations $(\mathrm{Li}, 2004)$.

Two well-known theorists, Pierre Bourdieu and James Coleman, both agree that social capital can be defined as resources embedded in relationships among actors and contains two dimensions: social networks and resources (Hauberer, 2011). However, both theorists construct social capital in different contexts. Perhaps most useful (as well as applicable) for this particular study concerning Punjabi immigrant women is Coleman's theory of social capital. For Coleman (1988), social capital was defined as the obligations, norms and information acquired by a person from his or her network. Coleman's theory of social capital relied heavily on the fact that humans are "rational" actors. Coleman (1988) argued that there are three main resources available for rational actors. The first resource is the set of obligations a relation might feel. For instance, "if $A$ does something for $B$ and trusts $B$ to reciprocate in the future, this establishes an expectation in $A$ and an obligation on the part of $B$ " (Coleman, 1988, p.102). Thus, this 
obligation becomes a resource actor $A$ can employ in the future. The second resource refers to the presence of norms that encourage people to help each other. The second resource is useful in analyzing if any Punjabi cultural norms play a role in helping immigrant women enter the trucking industry. Lastly, the third resource is information, which refers to the knowledge that people to whom an actor is connected possess. In Coleman's approach, social capital is understood as something that facilitates the attainment of collective goods. Coleman also highlights that social capital is an essential resource in families, in particular, since it promotes generational relationships between parents and children and which in turn, can enhance not only socialization but also educational attainment (Mooney, 2006).

French Marxist social theorist, Bourdieu, believes that social capital represents but one of the different forms of capital, which emerge in capitalist society, here taken to refer to the networks of connections an individual possesses or has access to (Mooney, 2006). Bourdieu's use of the term social capital can provide a coherent theoretical framework of social interactions and their economic and social outcomes. Bourdieu identifies "three dimensions of capital, each with its own relationship with class: economic, cultural, and social capital” (Ballet, Requiers-Desjardins, and Sirven, 2007, p.360). For Bourdieu, cultural social capital refers to shared norms, values, attitudes, and beliefs. Social capital may refer to the set of resources available for individuals in a social context, whereas cultural capital refers to the cultural contexts made up of norms, shared beliefs, values and so on (Ballet, Requiers-Desjardins, and Sirven, 2007). Furthermore, the combination of cultural and social capital helps convert forms of capital into symbolic capital. Although Bourdieu's approach to social capital looks at class, 
critics have argued that the broader theory of social capital generally ignores race, class and gender.

According to Kazemipur (2008), there is a linkage between social capital and the three standard sociological variables of class, gender and race/ethnicity. As Kazemipur argues (2008), "social capital is not a so-called independent variable; rather, it is affected by class divisions and income inequalities in society" (p.3). Although the theory of social capital is useful in describing how capital plays a significant role in determining economic and social success, it fails to answer how people make social ties and networks. Coleman, as well as many other theorists, have dedicated extensive literature to the benefits of social capital but have failed to address how social ties, which provide access to resources and labour opportunities, are made. Thus, incorporating and understanding the process of how immigrants make their connections and networks can definitely help enrich this case study. Furthermore, many critics argue that there is no coherent definition of social capital that allows for measurement (Mooney, 2006). However, for this particular case study, social capital will be measured by the incidence of social capital and its density, which will further be discussed in the methodology chapter. In the case of Punjabi immigrant women employed in the trucking industry, social capital can be useful since it can help deconstruct how immigrant women are able to enter a nontraditional occupation.

\section{2-The Importance of Social Capital within the Trucking Industry}

Studies available on the trucking industry generally tend to focus on health problems, economics, or the negative effects trucks may have on the environment, rather than focusing on social terms or the experiences of drivers. Very few studies have 
examined the role of social capital in the trucking industry. For instance, in Louisiana, Gardner (2000) has found that social capital played a major role in the oilpatch trucking industry since it was built upon the combination of social networks, kinship relations, and entrepreneurial activity. As demonstrated by Gardner (2009), truckers and clients in Louisiana heavily relied on social connections to find one another. Gardner uses Bourdieu's concept of social capital and describes it as "the sum of resources, actual or virtual, that accrue to an individual or a group by virtue of possessing a durable network of more or less institutionalized relationships or mutual acquaintance or recognition" (Gardner, 2000, p.394). An oilpatch trucker would generally rely on family or a high school buddy to further build network connections in the trucking business.

These networks were important since "the profit generated by a familial or social connection of significant stature could fuel the purchase of additional trucks and, eventually, allow the purchase of the operating permit necessary to form a trucking company" (Gardner, 2000, p.394). Owner-operators are largely responsible for finding their own work and within the oilpatch industry, social and familial networks provided the avenues through which careers traversed (Gardner, 2000). Gardner's (2000) study is a relevant source since it relates to the research reported in this case study on Punjabi immigrant women in the GTA's trucking industry. By studying the oilpatch trucking industry of a specific region of Louisiana, Gardner is able to provide an ethnographic account of how social capital, within communities, can determine labour market outcomes. Similarly, this case study will attempt to focus on the Punjabi immigrant community in the GTA in order to explore and analyze the factors that enable Punjabi women to enter the trucking industry. Another relevant study by Portes (1987) focuses 
on how the accumulation of social capital within ethnic enclaves has enabled Cubans in Miami to dominate certain industries, such as the truck transportation industry. According to Portes (1987), social networks within an ethnic community can play a major role in promoting its economic well-being. Portes' study is also relevant since it is one of the few studies that focuses on a specific community (Cubans in Miami), ethnic enclaves and social capital.

\section{3-The Benefits of Living in an Ethnic Enclave Community}

According to Galabuzi and Teelucksingh (2010), there are two dimensions that are often used to describe social capital: homogenous, which is related to what is called bonding capital, and heterogeneous, which is related to bridging capital. Homogenous refers to relations or ties among those of similar backgrounds or interest, whereas heterogeneous may refer to relations or ties that cross the boundaries of race, ethnicity, class, etc. (Galabuzi and Teelucksingh, 2010). In the case of Punjabi immigrant women, examining whether or not their ties are more homogenous or heterogeneous can help enrich the study. In Canada, studies have found that friends and family play a key role in helping immigrants decide where to immigrate and where to reside. Moreover, newcomers often use these informal networks to help them find a place to live and to adjust to their new host societies, including obtaining information about employment, education, etc. (Galabuzi and Teelucksingh, 2010). The Peel Region is home to several Punjabi ethnic enclave communities and Galabuzi and Teelucksingh's article, "Social Cohesion, Social Exclusion, Social Capital" (2010), is a relevant source since it focuses on Peel. By using Qadeer and Kumar's (2006) study on ethnic enclave communities in the Peel Region, Galabuzi and Teelucksingh (2010) demonstrated that ethnic enclaves in 
Peel are "largely an expression of preference, common interest, social networks and cultural or religious needs of immigrants and serve as a pathway for integration into Canadian society" (Galabuzi and Teelucksingh, 2010, p.21). Important to note is that the significance of the trucking industry in the GTA, particularly in the Peel Region, will further be discussed in the background chapter.

Furthermore, examining the "ethnic enclave economy" within ethnic enclave communities can further enrich this case study pertaining to Punjabi immigrant female truck drivers. Whether or not the ethnic enclave economy helps Punjabi women gain access to unlikely or nontraditional jobs is an important question to consider. An ethnic enclave economy refers to situations in which immigrants are employed in businesses with co-ethnics and operated by that same ethnic group (Galabuzi and Teelucksingh, 2010). According to Portes (1987), the ethnic enclave economy can promote minority female employment, especially among married women. Due to the absence of language barriers, it is easier for women to find employment in ethnic firms, which might prefer to hire co-ethnics (Portes, 1987). The ethnic enclave economy thesis stresses on the strength of ethnic solidarity, but it focuses less on transplanted cultural values and organization and more on the internal structure and relations of immigrant enclaves $(\mathrm{Li}$, 2004). Furthermore, "the strength of the ethnic enclave economy is premised on the growth in number and urban concentration of immigrants and the ability of the community to take advantage of ethnic ties and relations to develop a protected economy" (Li, 2004, p.180). Hence, the ethnic enclave economy thesis is useful in analyzing the urban or suburban concentration of Punjabi immigrants in a heavily industrialized area (the Peel Region), as well as examine how Indo-Canadians have 
become dominant within the GTA's trucking industry, which will further be discussed in the background chapter.

According to Agrawal (2010), examining the importance of geography and neighbourhood pattern in affecting family life and human service needs among newcomers is essential. Geography and neighbourhood patterns can help determine why many Punjabi men, as well as women to a lesser extent, are employed as truck drivers. The Punjabi community in the GTA is largely concentrated in certain areas of the Peel Region, which is heavily industrialized and home to various trucking transport companies. Contrary to the prevailing view in the United States and Europe, which is that "ethnic enclaves" are negative due to the ghettoization of immigrants, literature in Canada generally views ethnic enclaves in a positive light (Qadeer and Kumar, 2006). To what extent ethnic enclaves or the ethnic concentration of Punjabis in certain areas of the GTA play a role in increasing social capital, is an important question to consider. According to Agrawal, some advantages of ethnic enclaves include: ease of access to housing for immigrant-ethnics, sustenance of "community life" and help fostering social networks, promoting the viability of community-based facilities, laying the basis for ethnic economy and the emergence of ethnic business districts, etc. (Agrawal, 2010, p.34). Furthermore, ethnic enclaves in Canada are believed to outweigh the disadvantages since enclaves are largely expressions of preferences, social networks, common interests, norms, and the cultural and/or religious needs of their residents.

Moreover, ethnic enclaves can serve as the basis for the integration into the Canadian economy and society, as well as become helpful to women who are not fluent in English and who are accustomed to the supportive presence of friends and relatives 
(Agrawal, 2010). It is important to note that Agrawal's study "Neighbourhood Patterns and Housing Choices of Immigrants" (2010) is broad in context and does not focus on any specific community. Agrawal's research lacks qualitative data that could have enhanced the study since the viewpoint of immigrants themselves is necessary in determining how social networks in ethnic enclaves facilitate better economic and labour market outcomes. Also, Agrawal failed to provide an in-depth analysis of ethnic enclaves in the Peel Region, even though his literature focuses on this particular region. Focusing specifically on Punjabi immigrant women from India can help fill the gap on literature pertaining to "South Asian" immigrants. The term South Asian in itself is very broad. Hence, focusing on a specific South Asian community will help give a better understanding of their settlement experiences, especially since there are religious, cultural, linguistic, etc., differences between the various South Asian communities. Also, it is important to note that certain communities from South Asia have a longer history of immigration to Canada. For instance, the Punjabi community from India has been in Canada longer than the Tamil community from Sri Lanka or Bengalis from India. The success and benefits of living in ethnically concentrated areas can also differentiate between various groups, depending on how long their communities have been established or institutionally complete in Canada.

Nonetheless, literature on ethnic enclaves is useful in understanding how communities form bonds and make social networks or ties, which is lacking in the social capital theory. Although social capital theory acknowledges the benefits of social networks, it cannot provide an in-depth analysis on how networks are made. To further understand the role of social capital in facilitating labour market outcomes for Punjabi 
immigrant women, understanding social capital in the broader Punjabi community or "South Asians" is needed. Thus, the next section will focus on social capital within the Punjabi community.

\section{4-Social Capital in the Punjabi Community}

Even though there is a large Punjabi immigrant population in the GTA and in British Columbia, reliable literature pertaining to social capital within the Punjabi community in Canada is lacking. However, Diditi Mitra's article, "Social Capital Investment and Immigrant Economic Trajectories: A Case Study of Punjabi American Taxi Drivers in New York City" (2009), can help fill the gap in literature concerning the Punjabi community and social capital. By interviewing 40 Punjabi American taxi drivers, Mitra (2009) demonstrates that the mobilization of social capital within the Punjabi community has played a significant role in improving their working conditions, which influences their decision to remain in the taxi business. Furthermore, Mitra (2009) argues "empirical evidence on immigration has clearly shown how mobilization of social capital via embeddedness in immigrant social networks explains the economic incorporation of immigrants into the labour market and the subsequent formation of immigrant employment niches" (p.69).

Hence, this literature is useful since it can help understand whether or not social capital influences Punjabi immigrant women to remain in the trucking industry, rather than just analyzing how it might enable them to enter the industry. Although Mitra's (2009) study focuses on the American context, it nonetheless can be compared to the Punjabi community in the GTA since the 40 participants described in the study share a similar culture, language, ethnicity, etc., as the Punjabi female truck drivers. However, 
Mitra's (2009) study only focuses on Punjabi men, which can be a major limitation.

Hence, this case study concerning Punjabi immigrant women truck drivers can help give voice to a group of people that have been marginalized and understudied.

Furthermore, Arti Nanavati’s article, "Social Capital and Labour Market Outcomes for South-Asia Born Immigrants in Canada" (2009), is a relevant source since it helps fill the research gap in studies related to social capital and labour market outcomes for South Asians in Canada. However, Nanavati's (2009) study does not focus on a specific gender or a specific ethnic group from South Asia, which means that the results of the study are broader in context. According to Nanavati (2009), "social capital in the form of family, friends and other social networks impacts the labour market, through providing help in job search, affecting selection of occupation/s, enhancing upward mobility on the job ladder, and increasing earnings" (p.6). For the study, Nanavati (2009) used data contained in Equality, Security and Community Survey 2002, and divided the respondents into three categories: All (4450), South Asia (142), and India (100). Nanavati (2009) further used logistic regression analysis and in-person questionnaire methods to analyze social capital as a predictor in labour market outcomes. Nanavati's (2009) qualitative and quantitative study on South Asian and Indian immigrants concludes that social capital does play a role in determining labour outcomes, but men are more likely to benefit from social capital than women. However, Nanavati fails to reveal the precise number of male and female respondents, but does mention that the female participants were much lower than men. Hence, without an equal sample size of both genders, concluding that women are less likely to benefit from social capital can be less valid or reliable. Furthermore, Nanavati fails to adequately explain why the 
unusual categories for the participants (All, South Asia, India) were created. For immigrants, social support systems are essential since they help provide employment opportunities, which enable immigrants to integrate more quickly into the labour market of their host society. Since Nanavati does not focus on a specific ethnic group, her results are too broad and cannot be generalized to the entire South Asian population. Hence, by focusing on an ethnic group from South Asia (Punjabi immigrant women), this case study can depict a glimpse of reality that is often unnoticed by the mainstream, as well as help understand why only a specific ethnic group from South Asia is beginning to dominate the GTA's trucking industry.

Another relevant article by Chaze and George entitled, “ “Tell Me What I Need to Know": South Asian Women, Social Capital and Settlement" (2009) can help shed light on how immigrant women from South Asia get access to social capital. Chaze and George (2009) reported on the findings of in-depth qualitative interviews with 50 South Asian immigrant women in Toronto regarding their settlement needs and the role of social capital in meeting these needs. The purpose of Chaze and George's (2009) study was to examine the context and process of formation of social capital in the South Asian community, explore newcomer South Asian women's access to social capital present in the community, and to examine the settlement outcomes for newcomer women as a result of the use of social capital (p.266). Also, Chaze and George used social capital and social networking interchangeably in their study. Since there are limited resources on South Asian immigrant women and social capital in Canada, this literature is useful because it discusses the concept of social capital and its role in the migration and settlement experience of immigrant women in the host society. 
Chaze and George's (2009) study found that the participants in the study relied on informal networks of friends and relatives as the most exhaustive and specific source of information and orientation. Similarly, whether or not Punjabi immigrant women rely heavily on informal networks and relatives in helping them enter the trucking industry is an important question to consider. As Chaze and George (2009) argue, social support and social network (social capital) available to individual immigrants within their immediate family, kin and ethnic community plays a major role in facilitating their settlement and adaptation (p.266). According to Chaze and George (2009), immigrant women in Canada can be seen as more vulnerable because they experience many barriers to settlement as a result of the intersecting oppressions of race, gender, class, ethnicity, and age. This raises an important question regarding the settlement experience of Punjabi immigrant women in the GTA since it would be interesting to analyze whether or not the "intersecting oppressions" of race, class, gender, etc., has had an impact on female truck drivers.

For Punjabi immigrant women from India, it is important to note that the vast majority enter Canada as Family Class applicants, either sponsored by their husbands or family members. Generally, immigrant women are more likely to be admitted under the Family Class category and in 2009, women made up 59\% of all immigrants admitted from this category (Chui, 2011). Also in 2009, immigrant women represented only 19\% of all Economic Class principle applicants, which indicates that women are less likely to come as economic principle applicants in comparison to the Family Class or the spouse or dependent of an economic applicant (Chui, 2011). According to Bagga (2007), the Punjabi-Sikh community has a strong sense of group collectivity, rather than a sense of 
individuality, due to the community overwhelmingly relying on family class sponsorship. Moreover, "the kinship and co-ethnic networks in which immigrants are embedded are thought to impact on every aspect of the migration process, the decision to immigrate, the choice of destination, and ultimately, the adjustment of immigrants to their new countries" (Chaze and George, 2009, p.267).

Although there is a lack of research on how the Punjabi community in Canada benefits from social capital in terms of labour market outcomes, recent literature on the political success of minority Punjabi-Sikh MPs in parliament can be useful. According to Bagga (2007), "studies on minority involvement in politics have pointed to the importance of ethnic communities as resources through which candidates from such groups can build social capital, which can easily be translated into political capital" (p.161). For Punjabi-Sikhs, there exists a highly developed and thriving community in Brampton and Mississauga with numerous Gurdwaras, cultural organizations, sports clubs, media outlets, senior groups, and other associations based in the area (Bagga, 2007). According to 2001 statistics, Punjabi-Sikhs represented less than $1 \%$ of Canada's population but held approximately $2 \%$ of the 308 seats in the House of Commons (Bagga, 2007, p.161). Similarly, Indo-Canadians approximately form $65 \%$ of the GTA's truck drivers, which is an astonishing accomplishment considering the minority status of Indo-Canadians in comparison to the dominant majority (Aulakh, 2009). How immigrant men became dominant within the GTA's trucking industry will further be discussed in the next chapter.

Although the data presented by Bagga (2007) can be considered outdated since the population of Punjabi-Sikhs has increased since 2001, it nonetheless helps provide 
some context and valuable information pertaining to Punjabi immigrants and their "success" in politics. However, a more in-depth analysis could have enhanced the literature, as well as more extensive research on how social capital in the community gets formulated into political capital for Punjabi-Sikh candidates. In order to understand how racialized immigrants became important players within the GTA's trucking industry, the next section will focus on the background of the trucking industry. In particular, examining the effects of deregulation within the trucking industry will help understand why the number of racialized immigrants and women drivers within the industry, dramatically increased after the late 1980s. 


\section{CHAPTER 3}

\section{The Trucking Industry: A Background}

The freight trucking industry is extremely important to the Canadian economy. Having an efficient freight transportation industry is key to providing effective movement of raw materials and finished products. At some point or another, a truck has delivered almost anything one can think of. The Ontario Trucking Association even has a famous advertisement that shows the only thing not delivered by a truck-a baby (Shepard, 2009). As Hejazi and Haghani (2011) demonstrate, maintaining the availability of raw materials and providing fast and reliable delivery of final products helps support trade, production, and consumption activities.

\section{1-Economics of the Canadian Trucking Industry and the Effects of Deregulation}

The Canadian trucking industry, which includes 56, 800 firms, consists of: forhire carriers (hauling freight for compensation), private carriers (companies hauling their own freight), owner-operators (individuals who own and operate their own trucks and operate as independents for-hire truckers, hauling trailers for other carriers or directly for a shipper) and courier firms (couriers operate trucks for delivering same-day, overnight or later letters and parcels), (Transport Canada, 2011). Truck driving is a growth industry in Canada and in 2010, trucking firms employed 201, 000 persons, including 128, 000 salaried drivers, and an additional 54, 000 owner-operators (Transport Canada, 2011). In 2011, for-hire trucking activity increased and its real gross domestic product (GDP) was 6.3\% higher than in 2006 (Transport Canada, 2011). Furthermore, Canada and the United States exchange the world's highest level of bilateral trade, valued in 2000 at $\$ 1.4$ billion a day, in which two-thirds of it travels in trucks (Madar, 2000). In 2011, "the total 
value of Canada-U.S. trade (inbound and outbound) increased more than $9 \%$, with nearly $82 \%$ of Canadian road-based exports to the U.S passing through border crossings in Ontario and Quebec" (Transport Canada, 2011, p.91).

Much of this development within the trucking industry has been the result of two major reforms in Canada and the United States: free trade and deregulation. Free trade removed restrictions to commerce and deregulation removed restrictions to transportation (Madar, 2000). Regulation severely restricted both price and entry competition within the trucking industries. According to Madar (2000), trucking regulation made the state the pivotal actor in both countries and stemmed from the Great Depression and from government efforts to remedy the same problems - distress in the railway industry and turbulence in the trucking industry (p.5). Since trucks were becoming a faster means for delivering goods, the railway industry was interested in limiting the growth of trucking. In Canada, trucking developed quickly in the 1920s and by 1928, the two national railways began a concerted political effort to get truckers regulated (Madar, 2000). The state "controlled entry into the industry, the domains of each carrier, terms of business with shippers, and the conditions of growth and change" (Madar, 2000, p.11). The entry controls governed the number of carriers, whereas route controls specified exactly which segments of the public roads they might use (Madar, 2000). Furthermore, commodity controls governed what carriers might haul on which segment and in which direction, and rate controls specified what they could charge (Madar, 2000). Under regulation, as Madar (2000) demonstrates, trucking was a highly structured industry, with each sector serving particular parts of an elaborately partitioned market, and "in these visible ways, trucking regulation was the state in action" (p.11). 
In Canada, deregulation began in the late 1980s with the 1987 Motor Vehicle Transport Act (MVTA). The MVTA was part of a national reform regarding transportation policy and it was directed towards interprovincial trucking. By 1989, the provinces had implemented the new regulatory standards that were set out by the MVTA and Ontario was the first province to introduce a legislative response. On January 15, 1989, the economic deregulation of the fore-hire trucking industry became law in Ontario with the passing of the Truck Transportation Act (TTA), (Woudsma and Kanaroglou, 1996). According to Woudsma and Kanaroglou (1996), the TTA essentially opened entry into the for-hire trucking industry within Ontario, reducing the powers of the regulatory board concerning the issuance of licenses over a five-year period. The most prominent reforms in the TTA concerned the phased-in removal of entry control and the easing of license restrictions. Due to these reforms, over 13, 000 applications for new licenses or extensions were received by the regulatory board in the first year and a half following the implementation of the TTA (Woudsma and Kanaroglou, 1996). Eventually, deregulation liberalized the trucking industry since it allowed motor carriers to offer the services they wished and to negotiate prices individually with shippers (Madar, 2000). The trucking industry now operates without any economic regulation and the remaining requirements for industry entry relate to health concerns and proper insurance coverage.

Since deregulation occurred in the late 1980s, carriers have adjusted and learned to move in the fast and changeable currents of an open market. Furthermore, deregulation has enabled more minority groups to enter the trucking industry, which was overwhelmingly dominated by white males. For instance, in the United States, Gardner (2002) studied the oilpatch trucking industry in Southern Louisiana and found that 
industrial restructuring of the industry enabled more women and African-Americans to enter the business. Under regulation, power within the oilpatch industry was lodged in the communities and families of southern Louisiana and social networks were the mechanism for organizing the trucking sector of the industry (Gardner, 2002). However, deregulation eroded the social template of the trucking business since alliances between trucking companies and oil service companies replaced the social and kinship links of the regulated oilpatch (Gardner, 2002).

Heywood and Peoples (1994) have suggested that since deregulation occurred in the United States, the employment of minority truck drivers would continue to increase because increased competition should raise the costs of discrimination. They proposed that firms in vigorously competitive industries, such as the trucking industry, have neither the profit nor latitude to discriminate (Heywood and Peoples, 1994, p.135). Based on similar reasoning, Peoples and Saunders (1993) provide evidence suggesting that trucking deregulation led to a narrowing of the black/white wage gap in trucking (Hirsch and Macpherson, 1997). According to the American Trucking Association's 2012 edition of ATA American Trucking Trends, "trucking employs 6.8 million people, including more than 3 million drivers. Of those drivers, $4.6 \%$ are women and $32.6 \%$ are minorities" (Truck News, 2012, p.10). These figures show that there has been a dramatic increase in the number of minority (e.g., African-American, Hispanic) truck drivers in the United States in comparison to 1970, in which African-Americans represented approximately $2.4 \%$ of the total number of over-the-road truckers (Heywood and Peoples, 1994). Although studies concerning the effect of regulation and discrimination are mainly based in the United States, they nonetheless can relate to the Canadian 
trucking industry since both countries shared similar regulatory rules. Similar to the American trucking industry, the number of racialized minority truck drivers within the Canadian industry increased after deregulation. Although deregulation is not the only factor that played a role in the increase of racialized minority drivers, it nonetheless helped ease entry into the industry.

Despite the enormous size and significance of the trucking industry to the economy, relatively little scholarly work has been done on the industry from a Canadian perspective. Furthermore, the increase of racialized minorities in the industry has also been understudied, as well as the role of female drivers. Although men dominate the trucking industry, one major change in recent years has been the increase of female drivers. According to Alan Boughton, who is the President of Trailcon Leasing Inc., the biggest and best change he has witnessed is the inclusion of women in an industry that was dominated by men (Boughton, 2012).

\section{2-Women and Immigrants in the Trucking Industry}

Although males dominate the trucking industry, the number of female truck drivers has been increasing since 1991. According to census data, women represented a little less than $4 \%$ of the jobs in this occupation in 2006 , a percentage that has still been rising slightly since 1991 (1\%), (Service Canada, 2006). Despite campaigns to promote non-traditional jobs, women still occupy a marginal place within the trucking industry (Dube and Pilon, 2006). While there are several factors that have contributed to this situation, the long hours and days spent on the road may be a drawback for women with young children or women wishing to start a family. 
There is also a growing proportion of immigrants and racialized minorities within the Canadian trucking industry. The most recent data available on the number of immigrants within the trucking industry is from 2001. According to the 2001 Census, $13 \%$ of truckers in the labour force were immigrants, which is up $88 \%$ since the 1991 Census (Dube and Pilon, 2006). Furthermore, "approximately one-third had been in Canada for less than 10 years in 2001, compared with 19\% in 1991" (Dube and Pilon, 2006, p.13). According to Chow (2006), in the last decade, there has been an increase in the percentage of drivers for whom English is their second language. As Chow demonstrates, "this is particularly true in B.C. and Ontario and the trend will continue as the carriers look towards this group and new immigrants for new drivers in an era of driver shortages" (Chow, 2006, p.129).

Furthermore, encouraging more women to enter the trucking industry can also help with the driver shortage dilemma, which is mainly caused by the aging Canadian population and the difficulties of finding qualified truck drivers. In the GTA, there is a high proportion of Indo-Canadian truck drivers and many of them have a Punjabi background. According to the Indian Trucking Association, more than 65 percent of truck drivers in the GTA are Indo-Canadians, and out of these thousands, there are probably a couple of dozen women who drive with their husbands (Aulakh, 2009). However, there is a high probability that there are more than "a couple of dozen" Punjabi immigrant women who are employed as truck drivers since several participants in the study believe that there are more women driving trucks than one might imagine. Nonetheless, the ambiguity surrounding the exact number of Punjabi female drivers or 
immigrants within the trucking industry make it a difficult topic for researchers to study, especially since the nature of the industry is very complex and always changing.

\section{3- Trucking in the Greater Toronto Area (GTA)}

One key market for the economy is the Greater Toronto Area (GTA), which is also the largest immigrant-receiving region in Canada. The GTA has been recognized as a key generator of goods movement, due to its historic role as the largest Canadian manufacturing center and as a major consumer center (Roorda et al., 2010). According to Roorda et al. (2010), "Highway 401 and Queen Elizabeth Way (QEW) are key trade routes within the Quebec City-Windsor-Niagara corridors that link Canadian manufacturing to U.S. markets, carrying more than 30,000 commercial vehicles and having an economic value of more than $\$ 1$ billion per day on some road segments" (p.114). The Peel Region, which consists of Brampton, Mississauga, and Caledon, is heavily concentrated with jobs in goods-movement transport, warehousing and related industries (Transport Canada, 2011). Additionally, truck activity in Peel represents about 25 percent of all truck activity in Ontario and there are approximately 2000 truck companies in Peel alone (Khaderoo and Saiyed, 2012). Furthermore, freight transportation and warehousing account for almost $11 \%$ of Peel's employment and about $\$ 1.5$ billion worth of goods move through the region every day (Khaderoo and Saiyed, 2012).

The Peel Region also has a high ethnic concentration of Punjabi immigrants from India. In particular, the City of Brampton, which is considered to be one of Canada's fastest growing cities, (mainly due to an influx of immigrants and major housing developments), is home to several Punjabi ethnic enclave communities. According to the 
2006 Census of Canada, 68240 individuals in Brampton reported Punjabi as mother tongue, accounting for $15.81 \%$ of the total population or $37.65 \%$ of the allophone population (Stittle, 2007). Allophone population refers to the population with a nonofficial language as mother tongue, which means that Punjabi remained the leading nonofficial language in Brampton, followed by Portuguese and Urdu (Stittle, 2007). The prevalence of the freight transportation industry within Peel and the ethnic concentration of Punjabi immigrants in certain parts of the region, is a possible factor that may have lead to the highly disproportionate number of Punjabi males employed as truck drivers in the GTA, and to a much lesser extent, Punjabi immigrant females.

\section{4-Issues within the Canadian Trucking Industry}

As previously mentioned, the trucking industry in Canada is facing a driver shortage dilemma. Truck driving is a relatively demanding occupation and recruiting qualified drivers is becoming a serious problem for the industry. According to the Canadian Trucking Human Resources Council (CTHRC), about 60\% of Canadian fleets are having trouble filling seats in company trucks, while more than half are finding it difficult to find owner-operators (Report on Transportation, 2012). The CTHRC reported, "thirty percent of industry employees are 45 to 54 years old, and $17 \%$ are 55 or older-accounting for $58 \%$ of Class $1 /$ A company drivers, $49 \%$ of owner-operators, and 44\% of truck/transport mechanics" (Report on Transportation, 2012, p.10). Furthermore, there is an insufficient pool of new entrants to the industry and qualified Class 1/A drivers (Class 1/A refers to the class of license one must obtain in order to drive a tractortrailer). Since very few drivers enter the industry directly from high school (16.7\% of Class 1/A test participants were under the age of 25)-recruiting and promoting the 
industry to the youth sector is difficult (Canadian Trucking Human Resources Council, 2007). In 2004 , only $5 \%$ of truckers were under 25 , compared with $15 \%$ in the labour force as a whole and just over one-quarter of truckers were between 15 and 34, whereas the proportion in the labour force as a whole was 37\% (Dube and Pilon, 2006).

Some major setbacks for recruiting youth includes the age requirement for drivers to haul freight into the United States (drivers must be 21 years of age or older) and the reluctance of truck companies to hire drivers who are less than 25 years of age due to insurance reasons. In 2006, the CTHRC surveyed 1,432 employers in the trucking industry and the majority of respondents reported that there were multiple factors that contributed to the shortage of drivers in the industry (Canadian Trucking Human Resources Council, 2007). The results of the survey showed "a significant proportion of employers (43.5\%) cited the working conditions of the occupation (i.e., long hours, poor quality of life, working away from home) as a key factor for the driver shortage" (Canadian Trucking Human Resources Council, 2007, p.4). Furthermore, the CTHRC (2007) reported that truck driver training programs might require some adjustments to suit the needs of certain groups. For instance, while females are more likely to have more hours in training than males, they are less likely to successfully pass the truck driving test and this finding suggests that the existing approach to training may be less suited to females than it is to males (Canadian Trucking Human Resources Council, 2007). Also, the cost of training can be a barrier for potential truck drivers, especially females and newcomers.

It is important to note that the current shortage of drivers is not due to an insufficient number of certified or licensed truck drivers. In 2001, statistics showed that 
there were more than 662,000 valid Class $1 /$ A holders in Canada but only a portion of these individuals were employed as or considered themselves to be a truck driver (Canadian Trucking Human Resources Council, 2007). As noted by the Canadian Trucking Human Resources Council (2007), the shortage of truck drivers is not a "supply side" issue but mainly a training/qualification issue. Furthermore, the trucking industry in Canada is not a homogenous sector. Hence, there is not one strategy for addressing the diverse human resource requirements of the industry but work needs to be done to develop a plan for effectively promoting and attracting potential drivers. Despite the shortage of drivers during a period of growth within the industry, trucking firms in the GTA are increasingly relying on newcomers for hauling freight. Moreover, Punjabi immigrants in particular play an important role in the GTA's trucking industry and Punjabis now own several trucking firms. Whether or not social capital is a major factor that enables Punjabi female drivers to enter a male dominated industry will further be discussed in this paper. 


\section{CHAPTER 4}

\section{Methodology}

In order to collect detailed information and data on a topic that has rarely been explored, qualitative research methods were, without a doubt, the most applicable for this study. Hence, the research presented in this study is based on qualitative data collected from 8 female participants through one-to-one semi-structured interviews. The one-toone interviews allowed more flexibility and gave more discretion to the participants in terms of their availability. The case study and qualitative approach was more suitable for the research since I attempted to explore and understand the phenomenon of Punjabi immigrant women entering the male dominated trucking industry. One key benefit of using the case study approach is that focusing on one area allows the researcher to deal with the subtleties and intricacies of complex social situations (Denscombe, 2007). According to Denscombe (2007), the in-depth study of relatively focused areas, the tendency towards small-scale research and the generation of thick descriptions mean that qualitative research scores well in terms of the way it deals with complex social situations (p.312). Since a substantial amount of participants are required for quantitative research methods, the qualitative approach seemed more realistic for this small-scale study since immigrant women driving trucks are still few in number.

\section{1—Sample Size and Recruitment Methods}

The primary participants in this study are Punjabi females who are currently employed as truck drivers or have been in the past. The sample size for the study consists of 8 females and all were required to meet the background criteria of being an immigrant from India, having a Punjabi background, residing in the GTA, and being employed as a 
truck driver either currently or in the past. The GTA includes Toronto, Peel Region, Durham, Halton and York. However, all of the participants in the study were recruited from the Peel Region. The age of the participants ranged between 25 and 39.

Although the initial plan was to interview 10 female truck drivers, a few potential participants were unable to schedule an interview due to the nature of truck driving work and busy work schedules. The majority of the interviews were conducted over the telephone and only one interview was in-person. The telephone and in-person interviews were audio recorded and stored securely. Since half of the participants were employed as long-haul drivers, they were only home 1 or 2 days a week so they preferred to answer questions over the telephone. The interviews averaged between 20-40 minutes each and the participants were asked both open-ended and close-ended questions. Close-ended questions concerned the age, ethnicity, marital status, etc., of the participants, whereas the open-ended questions generally concerned the experiences of female truck drivers, motivations for entering the industry, the role of networking, etc.

The main method for recruiting the participants was through snowball or network sampling. With snowballing, the sample emerges through a process of reference from one person to the next and each person can be asked to nominate two other people who would be relevant for the purposes of the research (Denscombe, 2007, p.17). For the research, the goal was to get referrals for potential participants and to branch out. Through personal contacts, a few participants who met the background criteria were contacted and asked to suggest any other Punjabi female truck drivers they might know. This method of recruiting participants was useful since it was easy, effective and time efficient. Also, participants expressed that they felt more comfortable being asked to 
participate in a study by a network, rather than viewing a recruitment advertisement and calling the researcher. The participants were recruited and interviewed between June and July 2012. All of the interviews were audio recorded and transcribed in the language in which they were taken, Punjabi and/or English. Informed consent was obtained from the participants either verbally or in-person.

\section{2-Measuring Social Capital}

The raw data collected through in-depth interviews was transcribed, coded and categorized under themes, which will further be discussed and analyzed. The aim of this process was to arrive at themes that can help explain the factors that enable Punjabi immigrant women to enter the trucking industry. To estimate whether or not Punjabi immigrant women had access to social capital, two approaches were used: i) incidence of social capital, i.e., whether it exists or not, and ii) its density (Nanavati, 2009). As Nanavati (2009) argues, it is generally understood that people do have some form of social capital but labour market outcomes do not only depend on social capital, but also on its density, such as the size of the network and how strong the ties are in terms of frequency of interaction. Hence, the participants were asked relevant questions pertaining to the importance of informal and formal networks, living in an ethnic enclave community, etc.

\section{3-Research Limitations}

The scope of the study is limited to Punjabi immigrant women from the Peel Region employed in the trucking industry. Punjabi immigrant women represent a small minority of truck drivers and this research cannot generalize to the entire population since only 8 women were interviewed. Although all of the women reported driving a truck 
with their respective husbands, it is important to note that this study focuses solely on the experiences and views of women. Due to limited time and the complex nature of being employed in the trucking industry, male truck drivers from the GTA's Punjabi community were not recruited or interviewed. Furthermore, analysis in qualitative research is usually time consuming and the data collected by the researcher depends on the time and resources available for the research project (Denscombe, 2007). Unfortunately, there is no literature available on Punjabi female truck drivers or even Punjabi male drivers. Hence, this research is unique since it attempts to explore a topic that has been ignored or understudied.

\section{4-Research Participants}

For the purpose of protecting the identity of participants, each participant was given a number with which their specific comments were associated, rather than using their names. Moreover, the various trucking companies the participants were employed for will not be identified or named in this study. A brief description of each participant is provided below.

\section{Truck Driver \#1-TD1}

27-year-old married woman from Punjab, India. She has three children and was a team driver with her husband for 2 years. She was a long-haul driver and worked for a small truck company that employed three other Punjabi female truck drivers. She lives in a community in which there are a large number of Punjabi immigrants. She is currently not driving a truck because she wants to stay home and be with her children. 
Truck Driver \#2-TD2

25-year-old married woman who came to Canada from Punjab, India, with her husband in 2008. She is currently employed as a long-haul team driver with her husband since July 2011. She frequently crosses the American-Canadian border and works for a large truck firm that is owned by co-ethnics. She is not an owner-operator but drives a company truck. Her husband and friends are her main support networks and many of her friends also drive a truck. Her main motivation for driving a truck is to gain more capital and to become settled in Canada.

Truck Driver \#3-TD3

39-year-old married woman who came from Punjab, India in 1995 and drove a truck for 8 years. She obtained her B.A., degree from Punjab and took English courses in Toronto. She has two children and drove a truck as a single driver and as a team driver with her husband. She has experienced driving a truck locally and as a long-haul driver. She enjoys driving a truck and being with her husband, who is currently still employed as a long-haul driver. She owns two trucks and is currently taking a break from work but hopes to join her husband soon as a team driver.

\section{Truck Driver \#4-TD3}

30-year-old married woman who came to Canada in 2002 from Punjab, India. She has three children and was a team driver with her husband for 2 years. She was a long-haul driver and worked for a large truck firm that employed four other Punjabi female truck 
drivers. She is currently not driving a truck because she is on maternity leave. She lives in a community in which there are a large number of Punjabi immigrants.

Truck Driver \#5-TD5

38-year-old married woman who has been driving a truck with her husband for the past 5 years. She came to Canada from Punjab, India and has lived here for 15 years. She has two children and lives in a community that is home to many Punjabi immigrants. She is a long-haul driver and crosses the American-Canadian border every week. She works for a large trucking firm and is an owner-operator.

Truck Driver\#6-TD6

35-year-old married woman who is currently a team driver with her husband. She is a long-haul driver and has been driving for the past 6 years. She has two children and has completed her B.A., degree in India. She has been in Canada for 10 years and immigrated from Punjab, India. She works for a large trucking firm that employs over 5 female truck drivers. She drives within Canada and usually makes trips from Toronto to British Columbia. However, she occasionally has to cross the border in British Columbia and deliver freight in Seattle.

\section{Truck Driver\#7-TD7}

38-year-old married woman who immigrated to Canada from Punjab, India in 1996. She was a domestic long-haul team driver with her husband for $4 \frac{1}{2}$ years. She has two children and lives in a community that has a large Punjabi population. She worked for a 
large trucking firm as an owner-operator. She has a M.A. in Punjabi and currently is not driving due to health reasons. However, she has found a new job in the social services sector but her husband continues to drive a truck.

Truck Driver\#8-TD8

38-year-old married woman who has been driving a truck with her husband for the past 3 years. She came to Canada from Punjab, India and has lived here for 7 years. She has two children and lives in a community that is home to many Punjabi immigrants. She is employed as a long-haul driver for a large trucking firm. She is an owner-operator and many of her relatives, including females, are also truck drivers. 


\section{CHAPTER 5}

\section{Findings and Overview of Recurring Themes}

\section{1-General Overview of the Results}

The broader aim of the research was to explore the phenomenon of Punjabi immigrant women entering the trucking industry. In terms of the type of truck the women drove, the participants described it as being either a tractor-trailer or an 18wheeler. At the time of the interviews, four participants were currently employed as a truck driver and 4 were currently not driving a truck. The participants were between 25 and 39 years of age and 5 out of 8 participants have lived in Canada for ten years or less. The average age of the participants was about 35 , which is lower than the average age of truck drivers in Canada. Furthermore, all of the Punjabi immigrant women reported that they drove a truck as a team driver with their respective husbands. All of the Punjabi women participants were married to a co-ethnic, who also immigrated from Punjab, India. Seven out of 8 participants had at least one child or more. Six out of the 8 participants were sponsored to Canada by their husband and the remaining 2 were sponsored by family members. Moreover, all 8 females were long-haul drivers and spent 4-6 days a week away from home. Out of the 8 long-haul drivers, 6 regularly crossed the American-Canadian border, 1 occasionally crossed the border and 1 was a domestic long-

haul driver. A domestic long-haul driver means that freight was delivered only within the boundaries of Canada. From the GTA, the female drivers delivered general freight to various destinations such as California, Montreal, Winnipeg, British Columbia, etc.

As mentioned in the background chapter, Canada and United States exchange the world's highest level of bilateral trade. In 2011, there were 10.5 million two-way truck 
border crossings at the American-Canadian border (Transportation in Canada, 2011). Hence, frequently crossing the American-Canadian border is the reason why all of the participants reported that it was necessary for them to obtain Canadian citizenship in order to ease entry and prevent applying for American visas. As a result, all of the 8 Punjabi immigrant women were naturalized Canadians. Four out of 8 participants were currently not driving a truck due to various reasons such as being on maternity leave, wanting to spend more time with children, taking a break from driving, and finding other employment. Two out of the 4 participants (TD3 \& TD7) that were not driving a truck had experienced being in the industry for $4 \frac{1 / 2}{2} 8$ years and TD7 stated that she did not intend to ever drive a truck again, whereas TD3 really enjoyed being a truck driver and could not wait to get back on the road with her husband. The majority of participants, 7 out of 8 , reported having at least over 2 years or more of truck driving experience. Only one participant, TD3, reported experiencing delivering freight as a solo driver but this was only as a local driver within the GTA.

Seven out of 8 participants owned at least one truck and reported working as an owner-operator. Furthermore, only one participant worked for a small truck firm whereas the rest worked for a larger trucking company. Depending on the size, a company may own a fleet of anywhere from two to a hundred trucks and owning over 50 trucks generally classifies as a large company (Dube and Pilon, 2006). Furthermore, 6 out of 8 female drivers worked for a company owned and operated by co-ethnics (Punjabis). All of the female drivers reported having extended family and co-ethnic friends who also worked within the GTA's trucking business, as well as extended family employed as truck drivers in other parts of Canada, such as British Columbia and Alberta. All of the 
women reported that the company that they worked for employed at least 2 to 5 other Punjabi immigrant women as truck drivers. Seven out of 8 participants had a female relative who also drove a truck. For instance, TD3 reported that she was one of the first Punjabi immigrant females to get her truck license and that her decision influenced two of her female relatives, as well as three of her female friends, to also get their truck license. All of the participants agreed that truck driving could be described as a "nontraditional" job for females due to the overwhelming majority of men employed within the industry. However, the participants also stated that Punjabi immigrant women getting their truck license and entering the truck industry is a recent trend and that the vast majority of immigrant women drivers they knew, were team drivers with their husband. All of the participants were recruited from the Peel Region and stated that they lived in a community in which there was a large population of Punjabi immigrants. Seven out of 8 participants reported that Punjabis were the dominant ethnic group within their neighbourhood.

\section{2-Motivations for Entering the Trucking Industry}

For most of the participants, the motivations for entering the trucking industry were generally similar. For instance, many of the participants cited the following reasons for entering the truck business: gaining more income, being unsatisfied with previous employment or job in the GTA, joining husband, future aspirations for starting own truck company/business with husband, trying something different and challenging, exploring Canada and the US, and the influence of friends and relatives within the GTA's trucking industry. Several of the Punjabi immigrant female truck drivers stated that they could potentially earn higher wages employed as a truck driver, in comparison with their 
previous job as a general laborer in a factory. Important to note is that most truck drivers are usually employed in other jobs prior to becoming a truck driver. For instance, analysis of EI (Employment Insurance) data concerning the period from 2001 to 2005 suggests that a significant proportion of drivers were previously employed in the construction, manufacturing and/or other services (taxi drivers, bus drivers, etc.) prior to their employment as a truck driver (Canadian Trucking Human Resources Council, 2007). Similarly, the Punjabi female truck drivers reported being employed in other occupations before entering trucking. For instance, TD7 stated that she was previously employed as a school bus driver and that her husband was working as a taxicab driver in the City of Toronto before he entered the trucking industry.

In 2004, the average weekly wage of a full-time trucker in Canada was $\$ 791-$ approximately $\$ 41,100$ per year, which is slightly higher than the average of all employees, which is $\$ 40500$ per year (Dube and Pilon, 2006). However, long haulage drivers generally earn more since they tend to work longer hours, and drivers working 70 hours or more per week averaged more than $\$ 1000$ per week in 2004 (Dube and Pilon, 2006). The income the participants earned from the trucking business varied between $\$ 40000$ to $\$ 100000$ depending on whether or not they were owner-operators, experienced in driving and knowledgeable about the industry, the number of trucks they owned, the hours spent on the road and length of the trip, etc. However, several of the participants kept mentioning that driving a truck these days has become more difficult, especially because of the high costs of fuel. Nonetheless, all of the participants agreed that truck driving, especially long-haul, is a difficult job due to the long hours spent away from home and children, the lack of sleep and proper eating habits, weather conditions 
during the winter season, lack of work holidays and benefits, lack of truck stop accommodations for females, etc.

\section{3-Recurring Themes Within the Results}

Common themes emerged from the data collected through interviewing Punjabi immigrant women who are currently employed in the trucking industry or have been in the past. In this case study, the data revealed that familial relationships were the most important factor that enabled Punjabi immigrant women to enter the trucking industry. For the Punjabi immigrant women drivers who were mothers, parents and in-laws played a major role in babysitting their children while they were on the road hauling freight with their husband. Moreover, the participants stated that their spouse played an important role in helping provide truck driving training, encouragement, support, etc. Another theme that emerged in the study was that all of the participants lived in one region of the GTA - the Peel Region. Additionally, 7 out of 8 participants stated that they lived in an ethnic enclave community in which Punjabi immigrants were the dominant ethnic group. Furthermore, becoming "settled" in Canada by earning a decent income and eventually owning a home, as well as starting their own trucking firm, were the main reasons for why the Punjabi women chose to enter the trucking industry. 


\section{CHAPTER 6}

\section{Discussion and Analysis}

\section{1-Incidence of Social Capital and the Density of Social Networks}

The social capital theory argues that people do better when they are connected to others because of goods inherent in social relationships (Small, 2009). In the case of Punjabi immigrant female truck drivers, strong familial relationships, as well as co-ethnic networks within the Punjabi community, played a vital role in terms of facilitating their entry into the male dominated trucking industry. The results of the study showed that all

of the Punjabi immigrant women participants were connected to networks and profoundly reliant on their networks (familial, friends, and broader Punjabi community, etc.) to help ease their entry into trucking. From the data, it is evident that Punjabi immigrant women had access to some form of social capital due to the fact that they were connected to various actors and possessed various relationships within the industry and the broader Punjabi community in the Peel Region. Not only did all of the spouses of the participants drive a truck, but also, all of the women reported having extended family members, friends, neighbours, etc., that were employed in trucking, which influenced them to join the business as well. Overall, the incidence of social capital for all 8 women participants was enormously high since husbands, friends, family and networks within the Punjabi immigrant community, played a vital role in facilitating entry into the trucking industry for the women drivers.

Furthermore, several of the participants stated that their spouse had at least one friend whose wife also drove a truck, and being aware of the existence of other Punjabi female truck drivers helped the women become more confident in their ability to operate 
an 18-wheeler. One driver stated, “...his [husband] friend's wife drove a truck, he told him your wife will be able to drive one as well, and he kept convincing him that his wife should drive a truck so we can have better income" (TD2). For some of the drivers, the sizes of their networks within the industry were enormous. For instance, some drivers had a wide-range of friends that were also employed in the GTA's trucking industry. As stated by one female trucker, "I have friends who drive trucks and relatives. I have two cousins who drive a truck, my aunt's daughter drives a truck and her sister-in-law does as well and recently my husband's cousin got her truck license" (TD3). Also, as stated by the same driver, "...my uncle owns a garage and he fixes trucks all the time, if anything ever happens we go to him for truck repairs, trucks always need repairs, and one of my other uncle has his own small truck company" (TD3). Another driver who works for a large company stated, “...maybe this company has like 50 trucks and Punjabis own it and most drivers are Punjabi but I think two are not Punjabi...everyone in the office speaks in Punjabi and I think those two guys sometimes might feel left out" (TD8). The density of networks of the Punjabi immigrant women drivers was quite enormous, and without the networks, entering the truck business would have been extremely difficult. Furthermore, results of the study showed that there was a tendency of Punjabi immigrant women to be influenced by other female friends or family to join the truck business.

Gardner (2002) argues that social capital and social networks play a dual role since it can be inclusionary for some and exclusionary for others. Not only does social capital and social networking comprise the bonds of communities and a system of organization, they also exclude some individuals from the very benefits produced by intensive systems of social capital (Gardner, 2002). Another driver who also worked for 
a Punjabi owned trucking firm stated, “...they were mostly Punjabi [the drivers], and many were couples and I think maybe there was one Sri Lankan couple that worked for the same company as me" (TD4). This finding shows that although social capital and social networking has enabled immigrants from the Punjabi community to enter the trucking industry, the trucking firms that are now owned and operated by Punjabi immigrants might have created strong social bonds that exclude other immigrant groups or only prefer to hire co-ethnics. However, geography and neighbourhood patterns may also play a role in why more Punjabi immigrants are disproportionately choosing to enter the GTA's trucking industry. In particular, The City of Brampton, and the Malton region of Mississauga, has a large Punjabi immigrant population. One driver stated, “...the reason why I do not live in North York anymore is because moving to Brampton was easier for my husband and I to get to the yard and visit the truck company we worked for" (TD7), (A truck "yard" can be described as a safeguarded plot of land in which truck drivers could legally park their trucks 24/7). All of the drivers stated that the yard in which they parked their trucks was either located in Brampton, Mississauga or the North Etobicoke area. Hence, living in the Peel district, also home to 2000 trucking companies, was preferable to the participants.

The youngest and most recent immigrant female driver in the study stated, “...when I came from Punjab, my husband and I knew right away that we should drive a truck and where to live...we knew finding other job that pays as much as truck would be too difficult for newcomers like us" (TD2). In this sense, becoming employed as a truck driver and as a long-haul team driver with a spouse is seen as being a faster way of increasing one's socioeconomic status in Canada. Although doing well for the family is a 
common reason for why the women chose to drive a truck, the accumulation of social capital enabled women to financially provide for the family in a nontraditional way. Although TD2 was younger than 25 years of age when she started driving a truck, her husband was able to convince the truck company to hire her, even though her insurance costs were high. Furthermore, friends providing information and knowledge about the trucking industry to recent immigrants, such as TD2, played an important role in facilitating their entry into trucking. South Asian women newcomers may prefer to trust friends and relatives with the information and orientation they provide and prefer to act on their suggestions or recommendations (Chaze and George, 2009). For TD2, before coming from Punjab, speaking with friends in Canada about where to live, what jobs are available, etc., was important in terms of gathering information and making networks prior to arrival in the host country. On several occasions, all of the participants mentioned owning a nice suburban home and becoming "settled" in Canada as a main motivator for entering the truck business.

According to Agrawal (2010), “own -group preferences seem increasingly important in residential concentration, especially since new immigrant groups with high levels of human and financial capital are quickly able to realize their preference for residing with own-group members in neighbourhoods with high socioeconomic status" (p.5). Own-group preference means that residential concentration or ethnic concentration is the result of choice. Similarly, the participants stated that choosing to live in an ethnic enclave community was mainly their choice, but being closer to the trucking industry, as well as family and friends, were major factors for moving to the Peel Region or choosing to remain in Peel. 
This case study draws parallels with Nanavati's (2009) literature concerning social capital and the impact it has on labour market outcomes for South Asians and Indians. According to Nanavati (2009), social capital in various forms such as family, friends and other social networks impacts the labour market because it helps increase earnings, provide help in job search, and affect the selection of occupation. In this case study, the results have also shown that Punjabi immigrant women truck drivers were heavily influenced by social capital and social networks in terms of choosing an occupation, deciding where to live, increasing earnings from previous jobs, etc. For immigrants, social support systems help provide employment opportunities, and eventually, help them integrate more quickly into the labour market of the host society. For Punjabi immigrant women truck drivers, their spouse and parents and/or parents-inlaw were the most important informal networks.

\section{2-The Significance of Familial Networks for Punjabi Immigrant Women Drivers}

As noted previously, women drivers represent a very small proportion of truck drivers in Canada and one major reason for this is the difficulties of attracting women who have children or who are planning to start a family. Traditionally, women in families with children or with both spouses working generally take on a larger share of household responsibilities in comparison to men. Since long-haul drivers can be away from home up to 20 or more days a month, being a female truck driver can be tremendously difficult and stressful, especially for mothers. However, the data in this study revealed that one major factor that enables Punjabi immigrant women to enter the trucking industry is the fact that they live in an extended family household. More specifically, while employed as a truck driver, 6 out of 8 participants lived in an extended 
household. All of the participants who had children (7 out of 8) reported that their parents or in-laws played a major role in babysitting their children while they were on the road delivering freight with their husbands. One driver stated, “...they [parents] help with taking care of my 2 children so in terms of that I'm not worried because I know my parents...they know how to take care of my kids, I trust them" (TD8). On average, the participants were absent from home 19-24 days a month while working as a long-haul driver. All of the participants who had children argued that sponsoring their parents or their husband's parents from Punjab, India enabled them to become more productive and enter the trucking industry. Hence, in the case of Punjabi immigrant women truck drivers, family sponsorship was extremely significant in facilitating their entry into the nontraditional occupation.

Without having grandparents at home to take care of grandchildren, a few of the drivers found it really difficult to remain in the truck business and decided to either send their kids to Punjab, India or to other relatives in the GTA. One driver stated, "In the beginning, my mother-in-law was not here in Canada, nor was my own mother, so I had a relative babysit my children, but when mother-in-law came, it was much easier because she lived with us" (TD7). Another driver, who decided to send her children to India, stated, "My kids were all under 5 years when I started driving truck. I didn't have anybody here looking after them...I had to send them to India, which was not easy for me. But my parents took good care of them" (TD1). The Punjabi immigrant women who had children stated that in the Punjabi culture, parents helping raise grandchildren is a norm, and in many cases, they feel obligated to assist in anyway they can, especially if they have been sponsored to live in Canada. Some participants also mentioned that in 
some cases, sending your own children to live with their grandparents in Punjab, India, is not that uncommon for Punjabi immigrants in Canada, especially when the children are still quite young.

However, most of the participants expressed feeling guilt when they left their children at home, or in one case, in another country. For instance, one driver expressed that she sometimes does not feel proud to be employed as a truck driver due to being away from what matters the most, her children, but she feels proud that she is able to provide for them. As stated by a driver, "sometimes when I drive, I think of my children and I miss some of their events and I feel guilty, my mother-in-law takes care of them, but I want to take a holiday sometimes so I could be with them" (TD5). One Punjabi immigrant woman stated,

For ladies it is hard when you have to leave your kids at home, but when you look at the benefits it makes their life easier because you can drive with your husband for two years, make more money then take some time off work and spend more time with your kids... when my kids were younger it was easier to leave them, I think leaving older kids behind is harder, but everyone has different opinions, but driving a truck is not that hard but leaving kids behind is hard, but after it becomes easier because there is high income in driving a truck, if you are experienced and know what you are doing and operate your own truck, and with that you can give your kids more security...but driving a truck is better then working in a factory. (TD4)

Gaining more money or 'capital' is a recurring theme within the results. Most of the participants expressed that they joined their husband as a team driver so that they can eventually own more trucks and start their own trucking company.

Coleman's (1988) definition of social capital as the obligations, norms and information acquired by a person from his or her network, can help explain to what extent the accumulation of social capital has an impact on Punjabi immigrant women truck drivers to enter the labour market, in particular, the trucking industry. As previously 
mentioned, acquiring information about the trucking industry from social networks within the Punjabi community played a major factor in determining labour market outcomes for the participants. For Coleman, the second resource in social capital refers to the presence of norms that encourage people to help each other. The Punjabi cultural norm of grandparents feeling obligated to help raise grandchildren has enabled Punjabi immigrant women to enter the trucking industry. In several cases, participants stated that speeding the process of sponsoring their parents was important to their settlement experience in Canada because it ultimately enabled them to join their husband as a team driver and start earning a higher household income.

Furthermore, the participants all stated that their husband played the most important role in terms of helping them train for the truck driving examination, road test, and learning about trucks in general. As one driver stated, “...my husband helped me a lot to get A-Z license, he is proud of me, I remember him teaching me how to set up the axels, and in snow time, sometimes we had to put on chains on the tires" (TD1). Another driver stated, "I personally did not find anything to be difficult when driving, my husband helped me the most, he encouraged me, also I liked driving a truck mostly because I could stay with my husband, and together we made more money" (TD3). Another participant stated that it is good for Punjabi women to drive trucks because "the husband and wife can stay together, which is important for their relationship" (TD1). Also, some participants mentioned that their husband preferred to work with their wife or other family members, rather than hiring a team driver. As noted by one participant, “...my husband started driving a truck many years before me... he was always fed up with his 
team driver for different reasons so I thought why don't I just join him and he agreed that it was a good idea" (TD6).

The findings of this research relate to Chaze and George's (2009) study since social support and social network available to Punjabi immigrant women within their immediate family, kin and ethnic community, played a major role in facilitating their settlement and adaptation. Similarly, as Chaze and George (2009) studied South Asian women in Toronto, they found that the participants relied on informal networks of friends and relatives as the most exhaustive and specific source of information and orientation. Like the South Asian participants in Chaze and George's (2009) study, the most frequently identified settlement needs of Punjabi immigrant women were housing, having a good paying job, as well as information and orientation about the labour market in Canada. For Punjabi immigrant women, information about the job market was mainly accessed through informal networks and none of the participants stated using any formal networks such as settlement organizations, agencies, etc. However, some participants recognized the role of the Punjabi media in the GTA in influencing more Punjabis to get their truck license and to start their career and life in Canada as a truck driver.

\section{3-Driving a Truck for More 'Capital' \& Access to Resources in Ethnic Enclaves}

One common factor that influenced Punjabi immigrant women truck drivers to enter the business was to gain more capital. Several of the women participants expressed that they felt an enormous amount of pressure to become settled in Canada, which to them, meant owning a home and starting a family. As one participant stated, 'I've been driving for 3 years now mainly because of more money, I used to work in factory before 
and it was very unstable, never knew when I will get laid off, I couldn't live like that"

(TD8). Another participant stated,

I want to drive a truck for at least one more year, working in a factory your whole life is difficult, my husband and I drive together and we want to make more money so we can own more trucks and make contacts and networks and then start our own business [truck company]...then we would benefit at the end because we won't have to work as much and we get some free time. In trucking industry, now many Punjabi couples drive together, they work 5-6 years then they make their contacts with customers...right now, our mission is to start our own business, this is why I like driving a truck, because in long-term it has benefits. (TD5)

The majority of participants were unsatisfied with their previous job, which was why they chose to start driving a truck. Important to consider in the trucking industry is the precarious nature of driving a truck. However, long-haul truck drivers are able to make a middle-class income, or potentially higher based on the number of trucks they own. For instance, a recent Punjabi immigrant female truck driver from the GTA who drives on her own, reported that she makes approximately $\$ 50$ 000-\$55 000 annually (Aulakh, 2009). The accumulation of social capital for Punjabi immigrant women drivers has enabled them to make higher than average wages, as well as influence their decision to leave one precarious job (factory worker, bus driver, etc.) for another precarious job (truck driver).

Moreover, entrepreneurial aspirations were also cited as being a main motivator for gaining more income. As Portes (1987) demonstrated, Cubans in Miami benefited from living in an ethnic enclave communities and from the ethnic economy, which was generated in the enclaves. Furthermore, the ethnic economy promoted female employment, and one reason for this trend was that wage work by members of the same family was seen as a means to generate enough savings to establish a business (Portes, 1987). Similarly, most of the Punjabi immigrant drivers expressed joining their husbands 
in the trucking industry so they can save enough money to buy more trucks, and eventually, start their own small truck business. Furthermore, the participants stated that living in an ethnic enclave community was beneficial and useful. For instance, one driver stated, “...when I go away on the truck I might need something, like my parents watch my children and they're so old, if they need help, my daughter is 3 and son is 6 , my Punjabi neighbors help my parents" (TD5). For Punjabi immigrant women who leave their children with their grandparents, living in a neighbourhood that has co-ethnic neighbours is important, especially since many immigrant grandparents do not speak English fluently. In the City of Brampton, Punjabi is the $2^{\text {nd }}$ most spoken language in the home. This implies that there is a strong ethnic attachment within the Punjabi immigrant population in Brampton.

As Li (2004) states, "forms of ethnic attachment are correlated in that those who retain their minority language also tend to maintain close ethnic ties with their ethnic community" (p.177). The results of the study have shown that Punjabi immigrant women retain a strong ethnic attachment to the Punjabi community, which in return, has allowed them to gain more social capital (networks) and have access to resources in ethnic enclave economies. According to Li (2004), ethnic enclave communities can enable immigrants to have access to more social capital because they might potentially create a thriving ethnic enclave economy. As Li (2004) argues, "rather than being handicapped by language and cultural barriers, ethnic affinity and cultural distinctiveness form the basis of labour recruitment for immigrant employers and allow them privileged access to the immigrant labour market” (p.180). As noted by Bagga (2007), the Punjabi community in Brampton and Mississauga are highly developed and thriving with 
numerous cultural organizations, religious institutions, media outlets etc. One participant stated, “...there are so many Punjabi ads on TV shows, radio and all over the newspapers for people to get their truck license and to attend truck driving school, so all this information influence the newcomers, especially Punjabi men" (TD7). The Punjabi media outlet in the GTA is thriving and as one participant stated, “...my son and daughter once even attended a Punjabi truck show with their dad and people displayed their trucks and showed off new purchased trucks and stuff" (TD4).

Important to note is that several of the Punjabi immigrant women implied that truck driving is a short term job for them, although a few have been employed in the industry for 6-8 years and plan to remain in the industry or go back to work as a truck driver after taking a break. What several of the women hoped to achieve was to save enough money in order to start their own truck company with their husbands. Ultimately, the results have shown that to a large extent, living in an ethnically concentrated community of Punjabi immigrants, has allowed Punjabi immigrant women drivers to gain more social capital since they are able to find employment, have easier access to resources, network with co-ethnics, and retain their close relationships with family.

\section{4-Does Race, Class, or Gender have an Impact on the Punjabi Women Drivers?}

For the most part, all of the participants stated that as female truck drivers, they did not encounter much discrimination or harassment from other male drivers since the majority of the time spent on the road was with their husbands. According to Bernard, Bouck and Young (2000), women who drive without a male partner are more vulnerable to discrimination and sexual harassment, having a male team driver may guard against such harassment and provide a source of social support. However, while driving a truck, 
a few participants felt that their gender prompted many "stares" from other male drivers and the general public, who might not be accustomed to seeing females driving an 18wheeler, especially immigrant females. As noted by one driver, “...sometimes people stare and it makes me not want to go outside of the truck because it makes me feel awkward, like at the gas pump sometimes I don't feel like coming out of the truck because people keep staring" (TD2). One driver, who experienced driving a school bus and truck, stated,

A few times I felt discrimination and it was because I'm in the big vehicle and others think I cannot drive, especially since I am a short woman, and even within my own community [Punjabi] I faced this once... most people don't like women going out on the truck because this profession is labeled to the men, and back home to [in Punjab], they think we should not drive a truck or bus because it is only for men to do so. (TD7)

Another driver mentioned, “... at first, my parents thought driving truck is pretty difficult for ladies, but I had to explain to them for awhile that women can drive the truck as well, like how women drive cars and buses, they can drive trucks" (TD5). However, the majority of participants stated that their parents or family did not have an issue with them driving a truck.

Furthermore, all of the participants stated that they did not encounter any racial discrimination while driving in Canada. However, a few participants felt that in the United States, they were more likely to face discrimination due to the colour of their skin. One participant stated that in America, sometimes people might confuse Punjabi truck drivers for being Mexican or part of another nationality. As one driver stated,

In America, I think we were in Indiana, a police officer stopped us and he gave my husband a ticket for not knowing English, but he [police officer] barely even spoke to us, he just asked us to pull over and he asked us one question then gave my husband a ticket for not knowing English...I know that truck drivers could get tickets for not communicating in English because of safety but in this case I 
thought it was unfair because we both know English but my husband just paid the fine to avoid any troubles. (TD8)

In truck driving, being able to communicate in English can be essential, especially when crossing the American-Canadian border. However, in the case of TD8, she felt as if the police officer looked at the colour of their skin and just assumed that they could not fluently speak English, which she considered to be unfair treatment. Aside from a few incidents, the female truck drivers generally felt that they were treated fairly but did note that it might take a while for society to recognize that truck driving is not just a "man's job." Furthermore, all of the participants stated that truck driving has increased their social and financial status in Canada and that they feel proud of the fact that they are driving a truck, or have been in the past. 


\section{CHAPTER 7}

\section{Conclusion}

Overall, this paper demonstrated that the accumulation of social capital within the Punjabi immigrant community in the GTA facilitated Punjabi women to have access to a nontraditional occupation, trucking. By interviewing Punjabi immigrant women, this paper was able to explore the growing trend of immigrant women truck drivers employed in the GTA's trucking industry. One of the main objectives of this research was to explore the factors that enabled Punjabi immigrant women to enter the trucking industry. The frequent incidence of social capital and the enormous density of networks for Punjabi immigrant women ultimately facilitated their integration into the labour market. Furthermore, cultural norms within the Punjabi community played a significant role in enabling women to have access to an unexpected occupation. The results in the research strongly demonstrated that familial networks within the Punjabi community played an important role in enabling Punjabi immigrant women to enter the trucking industry. Parents and/or in-laws of the Punjabi female truck drivers played a vital role in enabling the women to enter the truck industry since they took care of their children while the mothers were on the road hauling freight. Furthermore, the role of the husband in helping facilitate entry into trucking was significant for the Punjabi women drivers since it increased their confidence, helped them gain experience and learn the skills required for trucking. As a result of the social capital accumulated by the Punjabi immigrant women from various networks, norms, and resources, the women drivers were able to ease their entry into an industry that is overwhelmingly dominated by men. Moreover, through the data, it was evident that Punjabi immigrant women generated and gained 
extensive networks and resources by living in an ethnic enclave community. Hence, living in an ethnic enclave community helped the Punjabi immigrant women to gain more social capital.

Perhaps the most significant contribution of this research paper is the recognition of a "silent minority" within the GTA's truck industry, Punjabi immigrant women. However, further research is needed on the role of female drivers and immigrants within the Canadian trucking industry. Since deregulation occurred in the late 1980s, the number of minority and female truck drivers in Canada has been increasing. The Canadian trucking industry is currently facing a driver shortage dilemma and one way to recruit new drivers is to target more women, couples, and immigrant populations to become truck drivers. What this study demonstrates is that the entry and success of immigrants, and especially women, in the industry depends very much on the social capital they can draw on to support them. But in the long run, it will also depend on the industry and government's ability to hear from members of these populations regarding their experiences in the industry. In this case study, the participants provided a wealth of information regarding their experiences as truck drivers and it is noteworthy to mention a few of the concerns that were raised by the female drivers during the interviews. All of them expressed that some of the services available at truck stops fail to accommodate the needs of women, mainly the washrooms. Overall, many of the female drivers felt that truck stops in Canada should be more easily accessible. A few of them wanted to create more awareness about controlling traffic for the GTA highways and roads. Some of the female drivers even suggested that Canada should model some American highways and 
consider having separate lanes for trucks or even separate highways exclusively for trucks.

This study opens up a number of questions, both empirical and theoretical, for further research. Are there other such cases where the presence of social capital within ethnic enclaves has enabled women to carry out unconventional work or further their careers? Are ethnic enclaves always sources of positive social capital, or can they play an inhibitory role as well? To what extent are the women interviewed here exceptional, and to what extent have they, and others like them, been able to expand or redefine gender roles and identities within both the Punjabi / South Asian communities and the mainstream? How might one think more theoretically about their willingness to pursue difficult and unconventional work as a means to their goals of conjugality, good motherhood, and family advancement? 


\section{References}

Agrawal, S. K. (2010). Neighbourhood patterns and housing choices of immigrants. Region of Peel Immigration Discussion Paper, 1-29.

Archer, K., \& Berdahl, L. (2011). Explorations: Conducting empirical research in Canadian political science. (2nd ed.) Don Mills, Ontario: Oxford University Press Canada.

Aulakh, R. (2009, January 3). A silent minority takes the wheel. Toronto Star. Retrieved from

http://www.thestar.com/news/gta/article/561188--a-silent-minority-takes-the-wheel

Bagga, G. (2007). From the Komagatu Maru to six Sikh MPs in parliament: Factors influencing electoral political participation in the Canadian-Sikh community. Our Diverse Cities, 4, 161-165.

Ballet, J., Sirven, N., \& Requiers-Desjardins, M. (2007). Social capital and natural resource management. The Journal of Environment \& Development, 16 (4), 355374.

Bernard, T. M., Bouck, L. H., \& Young, W. S. (2000). Stress factors experienced by female commercial drivers in the transportation industry. Professional Safety, 49 (9), 20-26.

Boughton, A. (2012). Here we grow again. Report on Transportation, 50 (1), 1-15.

Canadian Trucking Human Resources Council CTHRC, (2007). Canada's driving force phase 2. Ottawa: Canadian Trucking Human Resources Council

Chaze, F., \& George, U. (2009). "Tell me what I need to know": South Asian women, social capital and settlement. Springer, 10, 265-282.

Chow, G. Human Resources and Skills Development Canada, (2006). Labour standards issues in the inter-provincial Canadian trucking industry. Ottawa: Human Resources and Skills Development Canada.

Chui, T. Statistics Canada, (2011). Immigrant women (Catalogue no.89-503-X). Ottawa: Statistics Canada.

Coleman, J. S. (1988). Social capital in the creation of human capital. The American Journal of Sociology, 94, 95-210.

Denscombe, M. (2007). The good research guide for small-scale social research projects. (3rd ed.). Berkshire, England: McGraw-Hill 
Dube, V., \& Pilon, D. (2006). On the road again (No. 75-001-XIE). Ottawa: Statistics Canada.

Galabuzi, G. E., \& Teelucksingh, C. (2010). Social cohesion, social exclusion, social capital. Region of Peel Immigration Discussion Paper, 1-45.

Gardner, A. M. (2002). The long haul from deregulation: Truck drivers and social capital in the Louisiana oilpatch. Human Organization, 61 (4), 390-398.

Hauberer, J. (2011). Social capital theory: Towards a methodological approach. Wiesbaden, Germany: Springer.

Hejazi, B., \& Haghani, A. (2007). Dynamic decision making for less-than-truckload trucking operations. Transportation Research Record, 2032, 17-25.

Heywood, J., \& Peoples, J. (1994). Deregulation and the prevalence of black truck drivers. Journal of Law and Economics, 37(1), 133-155.

Hiebert, D. Research and Evaluation Branch of CIC, (2009). Exploring minority enclave areas in Montreal, Toronto, and Vancouver. Ottawa: Citizenship and Immigration Canada.

Hirsch, B., \& Macpherson, D. (1997). Earnings and employment in trucking: Deregulating a naturally competitive industry In J. Peoples (Ed.), Regulatory Reforms and Labor Markets (pp. 61-112). Norwell, Massachusetts: Kluwer Academic Publishers.

Kazemipur, A. (2008). Social capital profiles: Immigrants and native-born in Canada. Prairie Metropolis Centre, 1-23.

Khaderoo, N., \& Saiyed, S. Transportation Planning Staff, Transportation Division, Public Works (2012). Peel region moving into action: Goods movement strategic plan 2012 to 2016. Mississauga: Region of Peel.

Lau, L. (2007). The language of power and the power of language: The usage of English by South Asian writers and the subsequent creation of South Asian image and identity. Narrative Inquiry, 17 (1), 27-47.

Li, P. (2004). Social capital and economic outcomes for immigrants and ethnic minorities. Journal of International Migration and Integration, 5(2), 171-190.

Madar, D. (2000). Heavy traffic: Deregulation, trade, and transformation in North American trucking. (pp. 1-253). Vancouver: UBC Press. 
Min, P. G. (1993). Korean immigrants in Los Angeles In I. Light \& P. Bhachu (Eds.), Immigration and entrepreneurship: Culture, capital, and ethnic networks (pp. 185-204). New Brunswick, New Jersey: Transaction Publishers

Mitra, D. (2009). Social capital investment and immigrant ethnic trajectories: A case study of Punjabi American taxi drivers in New York City. International Migration, 50 (4), 67-83.

Mooney, G. (2006). Social capital. In E. McLaughlin \& J. Muncie (Eds.), The Sage Dictionary of Criminology (2nd ed., pp. 385-389). London, England: Sage.

Nanavati, A. (2009). Social capital and labour market outcomes for South-Asia born immigrants in Canada. Metropolis British Columbia, 9 (10), 1-40.

Pawar, M. (2006). “Social” “capital?” Social Science Journal, 43, 211-226.

Peoples, J., \& Saunders, L. (1993). Trucking deregulation and the black/white wage gap. Industrial \& Labor Relations Review, 47 (1), 23-35.

Portes, A. (1987). The social origins of the Cuban enclave economy of Miami. Sociological Perspectives, 30 (4), 340-372.

Qadeer, M., \& Kumar, S. (2006). Ethnic enclaves and social cohesion. Journal of Urban Research, 15 (2), 1-17.

Roorda, M. J., Hain, M., Amirjamshidi, G., Cavalcante, R., Abdulhai, B., \& Woudsma, C. (2010). Exclusive truck facilities in Toronto, Ontario, Canada: Analysis of truck and automobile demand. Transportation Research Record, 2168 (41), 114 128.

Service Canada. Service Canada, (2006). Truck drivers. Retrieved from Government of Canada website:

http://www.servicecanada.gc.ca/eng/qc/job_futures/statistics/7411.shtml

Shepard, T. (2009, September 26). Women drive home trucking careers. Etobicoke Guardian. Retrieved from

http://www.zuza.com/community-story/43771-women-drive-home-trucking-careers/

Small, M. L. (2009). Unanticipated gains: Origins of network inequality in everyday life. New York: Oxford University Press

Stittle, B. Brampton Economic Development Office, Business Information and Competitive Policy Branch. (2007). Language, mobility, and migration, immigration and citizenship. Brampton: City of Brampton. 
Stone, M., Destrempes, H., Foote, J., \& Sharon Jeannotte, M. (2008). Immigration and cultural citizenship: Responsibilities, rights, and indicators In J. Biles, M. Burstein \& J. Frideres (Eds.), Immigration and Integration in Canada in the Twenty-first Century (pp. 103-135). Kingston, Canada: School of Policy Studies, Queen's University

Trailcon Leasing Inc. (2012). Labour shortages continue to dog trucking industry. Report on Transportation, 50 (1), 1-15.

Transport Canada. Minister of Public Works and Government Services, (2011). Transportation in Canada 2011: Comprehensive review (Cat. No. T123A/2011E). Ottawa: Author

Truck News. (2012, June). ATA trends report shows trucking clearly still the dominant freight mode. Truck News, 32(6), 1-78.

Woudsma, C. G., \& Kanaroglou, P. S. (1996). The impacts of trucking deregulation in Ontario: A market-specific analysis. Canadian Public Policy, 22 (4), 356-377. 